\title{
Selected bibliography of Susumu Ohno
}

Atkin NB, Mattinson G, Beçak W, Ohno S: The comparative DNA content of 19 species of placental mammals, reptiles, and birds. Chromosoma 17:1-10 (1965).

Beçak W, Beçak ML, Nazareth HRS, Ohno S: Close karyological kinship between the reptilian suborder Serpentes and the class Aves. Chromosoma 15:606-617 (1964).

Beçak W, Beçak ML, Ohno S: Intraindividual chromosomal polymorphism in green sunfish (Lepomis cyanellus) as evidence of somatic segregation. Cytogenetics 5:313-320 (1966).

Bender K, Ohno S: Duplication of the autosomally inherited 6-phosphogluconate dehydrogenase gene locus in tetraploid species of Cyprinid fish. Biochem Genet 2:101-107 (1968).

Beutler B, Nagai Y, Ohno S, Klein G, Shapiro IM: The HLA-dependent expression of testis-organizing H-Y antigen by human male cells. Cell 13:509-513(1978).

Ciccarese S, Ohno S: Two plasma membrane antigens of testicular sertoli cells and H-2-restricted versus unrestricted lysis by female T cells. Cell 13:643-650 (1978).

Drews U, Itakura H, Dofuku R, Tettenborn U, Ohno S: Nuclear DHT-receptor in Tfm/Y kidney cell. Nature New Biol 238:216217 (1972).

Drews U, Blecher SR, Owen DA, Ohno S: Genetically directed preferential X-activation seen in mice. Cell 1:3-8 (1974).

Epplen JT, McCarrey JR, Sutou S, Ohno S: Base sequence of a cloned snake W-chromosome DNA fragment and identification of a male-specific putative mRNA in the mouse. Proc natl Acad Sci, USA 79:3798-3802 (1982).

Fumihito A, Miyake T, Sumi S-I, Takada M, Ohno S, Kondo N: One subspecies of the red junglefowl (Gallus gallus gallus) suffices as the matriarchic ancestor of all domestic breeds. Proc natl Acad Sci, USA 91:12505-12509 (1994).

Galton M, Benirschke K, Ohno S: Sex chromosomes of the chinchilla: allocycly and duplication sequence in somatic cells and behavior in meiosis. Chromosoma 16:668-680 (1965).

Gehring U, Tomkins GM, Ohno S: Effect of the androgen-insensitivity mutation on a cytoplasmic receptor for dihydrotestosterone. Nature New Biol 232:106-107 (1971).

Grootegoed JA, Jutte NH, Rommerts FF, van der Molen HJ, Ohno S: Concanavalin A-induced attachment of spermatogenic cells to Sertoli cells in vitro. Exp Cell Res 139:472-475 (1982).

Gropp A, Ohno S: The presence of a common embryonic blastema for ovarian and testicular parenchymal (follicular, interstitial and tubular) cells in cattle, Bos taurus. Zeitschr Zellforsch 75:505-528 (1966).

Haseltine FP, Ohno S: Mechanisms of gonadal differentiation. Science 211:1272-1278 (1981).

Hitzeroth H, Klose J, Ohno S, Wolf U: Asynchronous activation of parental alleles at the tissue-specific gene loci observed on hybrid trout during early development. Biochem Genet 1:287-300 (1968).

Klose J, Wolf U, Hitzeroth H, Ritter H, Atkin NB, Ohno S: Duplication of the LDH gene loci by polyploidization in the fish order Clupeiformes. Humangenetik 5:190-196 (1968).

Lin S, Ohno S: The interactions of androgen receptor with poly(A)-containing RNA and polyribonucleotides. Eur J Biochem 124:283-287 (1982).

Lyon MF, Searle AG, Ford CE, Ohno S: A mouse translocation suppressing sex-linked variegation. Cytogenetics 3:306-323 (1964).

Mathai CK, Ohno S, Beutler E: Sex-linkage of the glucose-6-phosphate dehydrogenase gene in the family Equidae. Nature 209:115$116(1966)$.

Matsunaga T, Ohno S: Cellular immune response to non-MHC plasma membrane antigens. Transplant Proc 12 (3 Suppl 1):135140 (1980).

Matsunaga T, Cabilly-Horesh O, Terz D, Lee A, Christian L, Ohno S, Biro AP: Use of transgenic mice with human MHC class 1 gene (HLA-A2). Adv exp Med Biol 186:341-347 (1985).

Muramoto J-I, Ohno S, Atkin NB: On the diploid state of the fish order Ostariophysi. Chromosoma 24:59-66 (1968).

Nagai Y, Ohno S: Testis-determining H-Y antigen in X0 males of the mole-vole (Ellobius lutescens). Cell 10:729-732 (1977).

Ohno S: Sex chromosomes and microchromosomes of Gallus domesticus. Chromosoma 11:484-498 (1961).

Ohno S: The sex chromatin: its origin and nature. Mammalian Cytogenetics and related Problems in Radiobiology (Symp Brazil, 1962), pp 253-267 (Pergamon Press, 1964).

Ohno S: A phylogenetic view of the X-chromosome in man. Ann Genet 8:3-8 (1965). 
Ohno S: Single-X derivation of sex chromatin, in Moore KL (ed): The Sex Chromatin, pp 113-128 (Saunders, Philadelphia 1966).

Ohno S: Sex Chromosomes and Sex-Linked Genes (Springer, Berlin 1967).

Ohno S: The preferential activation of maternally derived alleles in development of interspecific hybrids. Wistar Inst Symp Monogr 9:137-150 (1969).

Ohno S: The spontaneous mutation rate revisited and the possible principle of polymorphism generating more polymorphism. Can J Genet Cytol 11:457-467 (1969).

Ohno S: Evolution by gene duplication (Springer, Berlin 1970).

Ohno S: An argument for the simplicity of mammalian regulatory systems: Single gene determination of male and female phenotypes. Nature 234:134-138 (1971).

Ohno S: Genetic implication of karyological instability of malignant somatic cells. Physiol Reviews 51:496-526 (1971).

Ohno S: Gene duplication, mutation load, and mammalian genetic regulatory systems. J med Genet 9:254-263 (1972).

Ohno S: Simplicity of mammalian regulatory systems. Dev Biol 27:131-136 (1972).

Ohno S: Ancient linkage groups and frozen accidents. Nature 244:259-262 (1973).

Ohno S: Protochordata, Cyclostomata and Pisces, in John B (ed): Animal Cytogenetics, Vol. 4/1 (Borntraeger, Berlin-Stuttgart 1974).

Ohno S: Major regulatory genes for mammalian sexual development. Cell 7:315-321 (1976).

Ohno S: Promethean evolution as the biological basis of human freedom and equality. Perspect Biol Med 19:527-532 (1976).

Ohno S: Sexual differentiation and testosterone production [editorial]. N Engl J Med 295:1011-1012 (1976).

Ohno S: Testosterone and cellular response. Birth Defects Orig Artic Ser 13:99-106 (1977).

Ohno S: The original function of MHC antigens as the general plasma membrane anchorage site of organogenesis-directing proteins. Immunol Rev 33:59-69 (1977).

Ohno S: Genes and the inner conflicts of being man. Perspect Biol Med 22:3-9 (1978).

Ohno S: Major sex-determining genes. Monogr Endocrinol 11:1-140 (1978).

Ohno S: The role of H-Y antigen in primary sex determination. JAMA 239:217-220 (1978).

Ohno S: Why not androgynes among mammals? Basic Life Sci 12:165-181 (1978).

Ohno S: Origin of intervening sequences within mammalian genes and the universal signal for their removal. Differentiation $17: 1-15(1980)$.

Ohno S: (AGCTG)(AGCTG)(AGCTG)(GGGTG) as the primordial sequence of intergenic spacers: the role in immunoglobulin class switch. Differentiation 18:65-74 (1981).

Ohno S: Evolution of genes by Epimethean hindsight. (The Japan Society of Human Genetics Award Lecture). Jinrui Idengaku Zasshi 26:97-99 (1981).

Ohno S: Original domain for the serum albumin family arose from repeated sequences. Proc natl Acad Sci, USA 78:7657-7661 (1981).

Ohno S: Evolution is condemned to rely upon variations of the same theme: the one ancestral sequence for genes and spacers. Perspect Biol Med 25:559-572 (1982).

Ohno S: The common ancestry of genes and spacers in the euchromatic region: omnis ordinis hereditarium a ordinis priscum minutum. Cytogenet Cell Genet 34:102-111 (1982).

Ohno S: Homology between coding and noncoding sequences within the human class I HLA antigen gene. Clin Genet 23:58-69 (1983).

Ohno S: Birth of a unique enzyme from an alternative reading frame of the preexisted, internally repetitious coding sequence. Proc natl Acad Sci, USA 81:2421-2425 (1984).

Ohno S: Repeats of base oligomers as the primordial coding sequences of the primeval earth and their vestiges in modern genes. $\mathrm{J}$ mol Evol 20:313-321 (1984).

Ohno S: Segmental homology and internal repetitiousness identified in putative nucleic acid polymerase and human hepatitis B surface antigen of human hepatitis B virus. Proc natl Acad Sci, USA 81:3781-3785 (1984).

Ohno S: Cellular oncogenes as the ancestors of endocrine and paracrine growth factors and their evolutionary relic status in vertebrates. Hämatol Bluttransfus 29:224-227 (1985).

Ohno S: Genes, evolution, and the immortality of the monophyletic germ line, in: Biology of Fertilization, Vol I (Academic Press, Oxford 1985).

Ohno S: The notion of primordial building blocks in construction of genes and transcriptional and processing errors due to random occurrence of oligonucleotide signal sequences. Adv exp Med Biol 190:627-636 (1985).

Ohno S: The Y-linked testis determining gene and H-Y plasma membrane antigen gene: are they one and the same? Endocr Rev 6:421-431 (1985)

Ohno S: Atavistic mutations reflect the long life span of dispensable genes. Hämatol Bluttransfus 31:493-495 (1987).

Ohno S: Early genes that were oligomeric repeats generated a number of divergent domains on their own. Proc natl Acad Sci, USA 84:6486-6490 (1987).

Ohno S: Evolution from primordial oligomeric repeats to modern coding sequences. J mol Evol 25:325-329 (1987).

Ohno S: Repetition as the essence of life on this earth: music and genes. Hämatol Bluttransfus 31:511-518 (1987).

Ohno S: The ancestor of the adaptive immune system was the CAM system for organogenesis. Exp clin Immunogenet 4:181-192 (1987).

Ohno S: Codon preference is but an illusion created by the construction principle of coding sequences. Proc natl Acad Sci, USA 85:4378-4382 (1988).

Ohno S: On periodicities governing the construction of genes and proteins. Anim Genet 19:305-316 (1988).

Ohno S: Universal rule for coding sequence construction: TA/CG deficiency-TG/CT excess. Proc natl Acad Sci, USA 85:96309634 (1988).

Ohno S: Intrinsic evolution of proteins. The role of peptidic palindromes. Riv Biol 82:341-343 (1989).

Ohno S: Modern coding sequences are in the periodic-to-chaotic transition. Hämatol Bluttransfus 32:512-519 (1989).

Ohno S: Grammatical analysis of DNA sequences provides a rationale for the regulatory control of an entire chromosome. Genet Res 56:115-120(1990).

Ohno S: Intrinsic evolution of proteins. The role of peptidic palindromes. Riv Biol 83:287-291 (1990). 
Ohno S: The first set of antigens confronted by the emerging immune system. Chem Immunol 49:21-34 (1990).

Ohno S: Many peptide fragments of alien antigens are homologous with host proteins, thus canalizing T-cell responses. Proc natl Acad Sci, USA 88:3065-3068 (1991).

Ohno S: To be or not to be a responder in T-cell responses: ubiquitous oligopeptides in all proteins. Immunogenetics 34:215-221 (1991).

Ohno S: How cytotoxic T cells manage to discriminate nonself from self at the nonapeptide level. Proc natl Acad Sci, USA 89:4643-4647 (1992).

Ohno S: Of palindromes and peptides. Hum Genet 90:342-345 (1992).

Ohno S: "Self" to cytotoxic T cells has to be 1,000 or less high affinity nonapeptides per MHC antigen. Immunogenetics 36:22-27 (1992).

Ohno S: A song in praise of peptide palindromes. Leukemia 7, Suppl 2:S157-S159 (1993).

Ohno S: Patterns in genome evolution. Curr Opin Genet Dev 3:911-914 (1993).

Ohno S: The cardinal principle of like attracting like generates many ubiquitous oligopeptides shared by divergent proteins. Anim Genet 25, Suppl 1:5-11 (1994).

Ohno S: Active sites of ligands and their receptors are made of common peptides that are also found elsewhere. $\mathbf{J}$ mol Evol 40:102-106 (1995).

Ohno S: Why ontogeny recapitulates phylogeny. Electrophoresis 16:1782-1786 (1995).

Ohno S: The Malthusian parameter of ascents: what prevents the exponential increase of one's ancestors? Proc natl Acad Sci, USA 93:15276-15278 (1996).

Ohno S: The notion of the Cambrian pananimalia genome. Proc natl Acad Sci, USA 93:8475-8478 (1996).

Ohno S: The origin of immunoglobulins and T-cell receptors is likely to be the cell death sensor of macrophages. Res Immunol 147:247-252 (1996).

Ohno S: The one ancestor per generation rule and three other rules of mitochondrial inheritance. Proc natl Acad Sci, USA 94:80338035 (1997).

Ohno S: The reason for as well as the consequence of the Cambrian explosion in animal evolution. J mol Evol 44:23-27 (1997).

Ohno S, Atkin NB: Comparative DNA values and chromosome complements of eight species of fishes. Chromosoma 18:455-466 (1966).

Ohno S, Beçak ML: Can a protein influence the fate of its own coding sequence?: the amino- and carboxyl-terminal regions of H1 histone. Proc natl Acad Sci, USA 90:7341-7345 (1993).

Ohno S, Beçak W, Beçak ML: X-autosome ratio and the behaviour pattern of individual X-chromosomes in placental mammals. Chromosoma 15:14-30 (1964).

Ohno S, Cattanach BM: Cytological study of X-autosome translocation in Mus musculus. Cytogenetics 1:129-140 (1962).

Ohno S, Christian L, Attardi B: Role of testosterone in normal female function. Nature New Biol 243:119-120 (1973).

Ohno S, Epplen JT: The primitive code and repeats of base oligomers as the primordial protein-encoding sequence. Proc natl Acad Sci, USA 80:3391-3395 (1983).

Ohno S, Epplen JT, Matsunaga T, Hozumi T: The curse of Prometheus is laid upon the immune system. Prog Allergy 28:8-39 (1981).

Ohno S, Epplen JT, Sutou S: Testis-organizing H-Y antigen as a discrete protein; its MHC restricted recognition and the genomic environment in which H-Y gene operates. Hum Genet 58:37-45 (1981).

Ohno S, Faisst E, Zenzes MT: Post-zygotic chromosomal rearrangements in rainbow trout (Salmo irideus Gibbons). Cytogenetics 4:117-129 (1965).

Ohno S, Geller LN, Kan J: The analysis of Lyon's hypothesis through preferential X-activation. Cell 1:175-181 (1974).

Ohno S, Gropp A: Embryological basis for germ cell chimerism in mammals. Cytogenetics 4:251-261 (1965).

Ohno S, Jainchill J, Stenius C: The creeping vole (Microtus oregoni) as a gonosomic mosaic. I. The 0Y/XY constitution of the male. Cytogenetics 2:232-239 (1963).

Ohno S, Kaplan WD, Kinosita R: A photographic representation of mitosis and meiosis in the male of Rattus norvegicus. Cytologia 23:422-428 (1958).

Ohno S, Kaplan WD, Kinosita R: Formation of the sex chromatin by a single X-chromosome in liver cells of Rattus norvegicus. Exp Cell Res 18:415-418 (1959).

Ohno S, Kaplan WD, Kinosita R: On the end-to-end association of the X and Y chromosomes of Mus musculus. Exp Cell Res 18:282-290 (1959).

Ohno S, Kaplan WD, Kinosita R: The basis of nuclear sex difference in somatic cells of the opossum Didelphis virginiana. Exp Cell Res 19:417-420 (1959).

Ohno S, Kaplan WD, Kinosita R: X-chromosome behaviour in germ and somatic cells of Rattus norvegicus. Exp Cell Res 22:535544 (1961).

Ohno S, Kato K, Hozumi T, Matsunaga T: Mouse immunoglobulin coding sequences for the heavy-chain variable region arose as repeats of the two short building blocks. Proc natl Acad Sci, USA 79:132-136 (1982).

Ohno S, Kittrell WA, Christian LC, Stenius C, Witt GA: An adult triploid chicken (Gallus domesticus) with a left ovotestis. Cytogenetics 2:42-49 (1963).

Ohno S, Klinger HP, Atkin NB: Human oogenesis. Cytogenetics 1:42-51 (1962).

Ohno S, Lyon MF: Cytological study of Searle's X-autosome translocation in Mus musculus. Chromosoma 16:90-100 (1965).

Ohno S, Makino S: The single X nature of the sex chromatin in man. Lancet I:78-79 (1961).

Ohno S, Makino S, Kaplan WD, Kinosita R: Female germ cells of man. Exp Cell Res 24:106-110 (1961).

Ohno S, Matsunaga T: The 48-base-long primordial building block of immunoglobulin light-chain variable regions is complementary to the primordial building block of heavy-chain variable regions. Proc natl Acad Sci, USA 79: 2338-2341 (1982).

Ohno S, Matsunaga T, Lee AD: The invariably present tryptophan loop as the core of all divergent antigen-binding pockets. Scand J Immunol 20:377-388 (1984).

Ohno S, Matsunaga T, Wallace RB: Identification of the 48-base-long primordial building block sequence of mouse immunoglobulin variable region genes. Proc natl Acad Sci, USA 79:1999-2002 (1982).

Ohno S, Morrison M: Multiple gene loci for the monomeric hemoglobin of the hagfish (Eptatretus stoutii). Science 154:1034-1035 (1966). 
Ohno S, Muramoto J, Christian L, Atkin NB: Diploid-tetraploid relationship among old-world members of the fish family Cyprinidae. Chromosoma 23:1-9 (1967).

Ohno S, Muramoto J, Stenius C, Christian L, Kittrell WA, Atkin NB: Microchromosomes in holocephalian, chondrostean and holostean fishes. Chromosoma 26:35-40 (1969).

Ohno S, Nagai Y: Genes in multiple copies as the primary cause of aging. Birth Defects Original Article Series 14:501-514 (1978).

Ohno S, Nagai Y, Ciccarese S: Testicular cells lysostripped of H-Y antigen organize ovarian follicle-like aggregates. Cytogenet Cell Genet 20:351-364 (1978).

Ohno S, Ohno M: The all pervasive principle of repetitious recurrence governs not only coding sequence construction but also human endeavor in musical composition. Immunogenetics 24:71-78 (1986).

Ohno S, Smith JB: Role of fetal follicular cells in meiosis of mammalian oocytes. Cytogenetics 3:324-333 (1964).

Ohno S, Stenius C, Christian LC, Beçak W, Beçak ML: Chromosomal uniformity in the avian subclass Carinatae. Chromosoma 15:280-288 (1984).

Ohno S, Stenius C, Christian LC, Harris C: Synchronous activation of both parental alleles at the 6-PGD locus of Japanese quail embryos. Biochem Genet 2:197-204 (1968).

Ohno S, Stenius C, Christian L, Schipmann G: De novo mutation-like events observed at the 6PGD locus of the Japanese quail, and the principle of polymorphism breeding more polymorphism. Biochem Genet 3:417-428 (1969).

Ohno S, Tettenborn U, Dofuku R: Molecular biology of sex differentiation. Hereditas 69:107-124 (1971).

Ohno S, Trujillo JM, Kaplan WD, Kinosita R: Nucleolus-organisers in the causation of chromosomal anomalies in man. Lancet II:123-126 (1961).

Ohno S, Trujillo JM, Stenius L, Christian C, Teplitz RL: Possible germ cell chimeras among newborn dizygotic twin calves (Bos taurus). Cytogenetics 1:258-265 (1962).

Ohno S, Weiler C: Sex chromosome behaviour pattern in germ and somatic cells of Mesocricetus auratus. Chromosoma 12:362$373(1961)$.

Ohno S, Weiler C, Poole J, Christian L, Stenius C: Autosomal polymorphism due to pericentric inversions in the deer mouse (Peromyscus maniculatus), and some evidence of somatic segregation. Chromosoma 18:177-187 (1966).

Ohno S, Wolf U, Atkin NB: Evolution from fish to mammals by gene duplication. Hereditas 59:169-187 (1968).

Ohno S, Yomo T: Various regulatory sequences are deprived of their uniqueness by the universal rule of TA/CG deficiency and TG/CT excess. Proc natl Acad Sci, USA 87:1218-1222 (1990).

Ohno S, Yomo T: The grammatical rule for all DNA: junk and coding sequences. Electrophoresis 12:103-108 (1991).

Rodin S, Rodin A, Ohno S: The presence of codon-anticodon pairs in the acceptor stem of tRNAs. Proc natl Acad Sci, USA 93:4537-4542 (1996).

Teplitz R, Ohno S: Postnatal induction of ovogenesis in the rabbit (Oryctolagus cuniculus). Exp Cell Res 31:183-189 (1963).

Wachtel SS, Ohno S, Koo GC, Boyse EA: Possible role for H-Y antigen in the primary determination of sex. Nature 257:235-236 (1975).

Weiler C, Ohno S: Cytological confirmation of female heterogamety in the African water frog (Xenopus laevis). Cytogenetics 1:217-223(1962).

Wolf U, Flinspach G, B-hm R, Ohno S: DNS-Reduplikatonsmuster bei den Riesengeschlechtschromosomen von Microtus agrestis. Chromosoma 16:609-617 (1965).

Wolf U, Ritter H, Atkin NB, Ohno S: Polyploidization in the fish family Cyprinidae, order Cypriniformes. Humangenetik 7:240244 (1969).

Yomo T, Ohno S: Concordant evolution of coding and noncoding regions of DNA made possible by the universal rule of TA/CG deficiency-TG/CT excess. Proc natl Acad Sci, USA 86:8452-8456 (1989). 